\title{
"Marrying Out" for Love: Women's Narratives of Polygyny and Alternative Marriage Choices in Contemporary Senegal
}

\author{
Hélène Neveu Kringelbach
}

Hélène Neveu Kringelbach is a lecturer in African studies at University College London. She is an anthropologist with a particular interest in Senegal, and has previously carried out research on dance in Dakar. Her monograph, Dance Circles: Movement, Morality and Self-Fashioning in Urban Senegal (Berghan, 2013), was awarded the 2013 Amaury Talbot Prize in African Anthropology by the Royal Anthropological Institute. Since 2011 she has carried out multisited research on binational marriage and transnational family relationships in Senegal, France, and the U.K.E-mail: h.neveu@ucl.ac.uk

\begin{abstract}
This article examines the ways in which childhood and youth experiences of living in polygynous households shape the aspirations of middle-class Muslim Senegalese women to companionate marriage. Increasingly, such aspirations are fulfilled through marriage with European men. In contrast to an enduring popular discourse according to which women live happily with polygyny throughout the Senegambian region, this article shows how some middle-class women's choice to "marry out" is explicitly linked to family narratives and personal experiences of suffering. In a context in which many of these women face strong familial opposition to marriage with non-Muslim European men, this article suggests that the women's narratives provide moral legitimacy to their "alternative" choices.
\end{abstract}

Keywords: Senegalese women; polygyny; marriage; companionate marriage; moral legitimacy; family narratives

\section{Introduction}

When I was a child living in France, my French mother would occasionally take me to Senegal to visit my Senegalese relatives there. Among my childhood memories of Dakar, one stands out: the memory of a polygynous household. ${ }^{1}$ We used to visit my fathers' relatives in one of the city's old quarters, the Medina, where I enjoyed spending afternoons at the neighbor's' home. Although only a child at the time, I was aware that this was a home rife with tensions. I learned that the husband in the household had made a love marriage with his first wife, but that they had remained childless for years. The man had eventually married a second wife, who was the mother of his children. The wives took turns cooking and sleeping in their husband's bedroom, and there were frequent arguments around food, clearly a symbol of the power relations within the household.

On one visit I was surprised to learn that the first wife had left altogether. As a young adult, I became reacquainted with the second wife's eldest daughter. She lived abroad and was married to a European man, with whom she had several children. She told me how painful it had been to grow up in a household with two wives, and how family relationships had been strained by the constant rivalry. Each wife believed the other had an unfair advantage: the first had been chosen out of romantic love, and the second had given birth to the children, a significant mark of female status in a society in which reproduction remains a central value in marriage. The daughter told me that she had known from an early age that she did not want this kind of life for herself. 
She was aware that European men did not necessarily make perfect husbands, but at least, she believed, they would not bring another wife into one's home.

This article examines the childhood and youth experiences of predominantly middle-class Muslim Senegalese women who have chosen to marry European men, often in the face of considerable familial opposition. The article asks why, in a context in which marriage ideals remain centered on familial alliances, reproduction, material security, and the fulfillment of religious obligations (Bop 1996; Dial 2008; Hannaford 2015), some women make alternative marriage choices, thereby compromising their moral status and their relations to their kin. I suggest that the answer is to be found in a disjuncture between rising ideals of companionate marriage among middle-class Senegalese women, on the one hand, and the resilience of polygyny on the other. I argue that these marriages choices are not as autonomous as they may appear, and that the women's narratives serve both to make sense of their experience and to establish their moral legitimacy as dutiful daughters and sisters, and as good Muslims. In a broader sense, the article considers the extent to which urban African women's aspirations to transnational lives transform ideas of marriage, love, and gender. And finally, since the empirical material is largely made up of life stories, the article considers the role of autobiographical narrative in linking past experiences and aspirations for the future. The narratives presented here are centered on a concern with gender relations in Senegalese polygynous households.

From a conceptual perspective, this article is informed by two strands of anthropological scholarship: the first deals with the global rise of the companionate marriage ideal and its social consequences, and the second deals with the social texture of cross-border marriage. In the first section, then, I discuss the broader scholarship on companionate marriage, particularly as it relates to Africa. I then move on to a discussion of marriage in Senegal in historical perspective, where I sketch the factors that may have contributed to the resilience of polygyny. Next I introduce family narratives from Senegalese women married to European men. In the testimonies I have selected, youth experiences of living with polygyny are contrasted with aspirations to monogamous, companionate marriage. The narratives are divided into two sections. The first captures the views of women who live in Senegal, and who tend to emphasize the link between polygyny and women's misfortune and unhappiness. The second section is similar but focuses on the narratives of women who live in France, who tend to be more explicit about their aspirations to romantic love and egalitarian gender relations, likely due to a stronger influence of feminist discourses in the French context.

This article draws on material collected for a broader research project funded by the Leverhulme Trust as part of the Oxford Diaspora Programme, and entitled "Multinational Families, Creolized Practices and New Identities: Euro-Senegalese Cases." "This on-going study involves more than fifty couples or former couples of different generations, divided almost equally between Senegalese women living with European men and Senegalese men living with European women. Most of the Senegalese women concerned could be described as middle-class (though not necessarily born into middle-class families). Most have at least a secondary school-level education, and some a university education. In this sense, the study reflects the class-based and gendered nature of binational marriage across Senegal and Europe.

The study draws on approximately ten months of fieldwork in France, two months in Senegal, and ad-hoc interviews in the U.K. between 2011 and 2015. In addition, the study draws on material collected in Senegal during a total of sixteen 
months of fieldwork between 2002 and 2011 in connection with an earlier research project (see Neveu Kringelbach 2013). Most of the interviews were conducted in French, with occasional incursions into Wolof. In most cases I interviewed European spouses separately, but the men's perspectives do not appear in this article since the focus is on the women's narratives. Having spoken to both spouses, however, and sometimes other family members as well, did help to contextualize the narratives.

My own background as the daughter of a French mother and a Senegalese father certainly facilitated access to these participants, but it may also have skewed some of the testimonies toward the more positive aspects of cross-border marriage. Out of concern with achieving as much reciprocity as possible in research, I often shared my own life story with my participants.

\section{Conceptualizing Companionate Marriage in Africa}

My interest in companionate marriage was inspired by many conversations and interviews with Senegalese women, both in Senegal and France, in which I brought up the subject of marriage and they would mention, spontaneously, that the marriages they had witnessed in their families did not correspond to their own ideals. Although they did not use the term "companionate marriage," their aspirations fitted well with Wardlow and Hirsch's (2006:4) definition of companionate marriage as "a marital ideal in which emotional closeness is understood to be both one of the primary measures of success in marriage and a central practice through which the relationship is constituted and reinforced." Thus defined, the term is broad enough to encompass a wide range of practices, or to borrow Burnham's phrasing (1987:50), to accommodate a "bundle of interactional possibilities." The notion of companionate marriage also implies, often, that the bond between the couple is privileged over other family tiesan emphasis that is regarded as a shift in societies in which a good marriage is understood as an alliance between families more than as a contract between individuals. As we will see, however, Senegalese women who have married outside the region often find themselves compelled to give family ties a central role in their lives, perhaps precisely because they have made a choice that is perceived as individualistic and therefore morally ambiguous.

In his illuminating review of the anthropological literature on marriage in Africa, Burnham (1987) reminds us that the nuclear family ideal as it is known in Europe and North America is a fairly recent phenomenon. He adds that the evolutionary notion that the nuclear, monogamous, family reflects a society's position on the highest rung of a scale of progress was promoted by post-World War II modernization theory (see also Goode 1964). Yet change is taking place, for as Wardlow and Hirsch (2006:1) point out, "around the world, young people are talking about the importance of affective bonds in creating marital ties, deliberately positioning themselves in contrast to their parents and grandparents." The Hirsch and Wardlow (2006) volume suggests that the global rise in the companionate marriage ideal may be explained as a phenomenon of late capitalism that also reflects the impact of global media and accompanies changes in religious practices and commitments. In Senegal the salience of romantic love in marriage is evident in music, in the tabloid press, and in the passion many women have for Latin American telenovelas. Could it be, then, that the increasing propensity by younger Senegalese women to "marry out" (genn xeet) has to do with a perception that Senegalese men are unable to offer companionate marriage? ${ }^{3}$

I focus on Senegalese women married to European men because experiences of 
polygyny are recurrent in their narratives, and because they are more likely than Senegalese men married to European women to be stigmatized for "marrying out." Because the narratives were collected several years after the women made these choices, their comments present a methodological challenge: there is no reliable way of knowing their motivations at the time of marriage. People choose a marriage partner for multiple reasons, some of which may not be entirely conscious or articulated. My aim, therefore, is not so much to piece together an emotional process in retrospect, as it is to understand the role played by the narratives in the present. Regardless of the women's thoughts at the time of marriage, it is significant that in their current explanations they made a connection between their experiences of gender relations within their families and their own marriage choices.

This article is also informed by the recent literature on love and marriage in Africa. In their illuminating review, Thomas and Cole (2009) point out that on the whole, scholars writing on gender, sexuality, and family on the continent have shied away from love as a subject of analysis. Yet Thomas's (2009), Fair's (2009), and Mutongi's (2009) contributions in the same volume show that by the mid-twentieth century there was already plenty of talk about romantic love and intimacy in the printed media in various parts of Africa. One must be wary, however, of viewing the importance of romantic love (bëggel) in marriage as a marker of transition toward a nuclear family ideal in Muslim Senegal. First, as Hannaford and Foley (2015:207) remind us, "spousal compatibility, intimacy, and love have long been part of the Senegalese conceptualization of marriage"; therefore, the ideal of emotional fulfillment in marriage is not new. Second, if this were a transitional period, the ambivalence women have expressed about polygyny in the past (Ames 1955; Diop 1985; Antoine \& Nanitelamio 1995) would have already rendered polygyny obsolete. Instead, according to popular opinion in Dakar, polygyny is alive and well across all social classes. This perspective is supported by the Senegalese press, which revels in stories about celebrities of both sexes choosing to enter polygynous marriages, as well as surveys that point to a slow decrease in polygyny rather than a complete disappearance. ${ }^{4}$

Rather than analyzing women's aspirations as a mark of decline in polygyny, therefore, I find it more fruitful to ask what those stories say about the narrators' ideas about love, marriage, and gender, and about their moral dilemmas. I suggest that the stories can be understood as an attempt to moralize the act of genn xeet in a social context in which women who cross too many boundaries in marriage risk being labeled as immoral.

This article is also informed by widespread assumptions that marriages between Senegalese women and European men are largely driven by economic need, the desire to migrate, or both. However, while keeping in mind the likelihood that individual ideas about marriage are always linked to aspirations for the future, this article challenges the widespread perception, increasingly emphasized in government discourses on marriage and migration, that intimate relationships between men from wealthier countries and women from poorer ones can be reduced to material exchanges or migration projects (see Charsley 2012). Certainly, these aspects may be present, but intimate relationships are always more complex. As Fernandez (2013:282) points out, the ideal of companionate marriage risks obscuring the ways in which, in any marriage, "emotions and materiality are deeply intertwined." Moreover, in some of the cases I have encountered, the Senegalese women were better educated or better off economically than their European husbands. In addition, some of the couples I interviewed lived in Senegal, so that the long-term migrant was the 
European husband and not the Senegalese wife.

Hannaford and Foley's (2015) recent study of marital and nonmarital strategies among Dakaroises would suggest that most women can no longer afford to make companionate marriage a priority. They argue that with the rising cost of living in urban Senegal and a decreasing ability by Senegalese men to fulfill women's expectations of material care, "women's processes of evaluating potential marital partners are deemphasizing historically important concerns with strengthening kin networks, formulating a long-term partnership, respecting class, caste, and ethnic endogamy, and establishing emotional intimacy in favor of a narrower calculus of immediate and individual material gain" (2015:211). But the different perspectives between our studies may be due to the different periods at which the marriages concerned took place: whereas most of my interviewees married in the 1990s or early 2000 s, it is likely that their participants devised their strategies more recently, in a context of rising inflation and unprecedented inequality.

When it comes to migrant spouses in Europe today, government discourses seem to serve the purpose of excluding undesired migrants as much as they are designed to root out actual "marriages of convenience." As a result, the role played by personal experience in cross-border marriage is often ignored. This article thus contributes to an emerging literature that foregrounds the entanglement of emotion, personal experience, life aspirations, and politico-legal structures in marriage across borders (see, e.g., Constable 2005; Salomon 2009; Bloch 2011; Charsley 2013; Rytter 2013; Cole 2014; Groes-Green 2014). Such entanglement is constructed differently depending on the context, and I now turn to histories of marriage practices in the Senegambian region.

\section{Senegalese Marriage in Historical Perspective}

Polygyny in Muslim Senegal has been more resilient than most people expected in the early years of independence. This seems to be the case across all ethnic groups; Antoine and Nanitelamio (1995), for example, did not find ethnicity to be a significant factor of variation in Dakar in the late 1980s and early 1990s. They also noted that Senegal had one of the highest rates of polygyny in Africa, surpassed only by Togo. Today many Muslim Senegalese women still expect to be living in a polygynous marriage at some point in their lives (Dial 2008), and it is likely that the different economic, cultural, and politico-legal factors that have sustained the practice over time continue to do so.

Marriage laws play a significant role, of course, although sometimes by their lack of effect. Indeed in the 1970s Senegalese women intellectuals had hoped that the 1972 Family Law, the Code de la Famille, would undermine polygyny by giving men the option to choose "monogamy" for life at their first marriage. But men and Muslim leaders in the rural areas, in particular, resented the intrusion of the state into family affairs, and as a result few polygyny-related conflicts were brought to the courts (Sow, Rennick, \& Boone 1989). Instead, women who wished to break up a marriage sometimes returned to their natal homes and waited there for senior relatives to resolve the conflict (Creevey 1996).

Economic and political factors have also been important in the persistence of polygyny. Ames (1955) thus saw polygyny in Wolof-speaking rural Senegal as an expression of the "wealth-in-people" ethos commonly documented in West Africa, where land had been plentiful but where labor had been scarce. He argued that Wolof women played such an important role in domestic work, reproduction, and food 
production that monogamous marriages placed an unbearable burden on the shoulders of single wives. This argument is still used to legitimize polygyny in contemporary Senegal, particularly from a male perspective. Diop (1985), who did research among rural Wolof populations much later, added that polygyny served to multiply alliances between lineages. A parallel range of studies has focused on the role of polygyny in expanding patrilineages, the prestige attached to procreation (e.g., Goody 1973), and (from Marxist-leaning scholars) the dimensions of exploitation and political power. Most famously, Meillassoux $(1960,1975)$ analyzed polygyny as the expression of gerontocracy in societies where older men delay the marriage of younger men by controlling their capacity to accumulate resources for bridewealth. In rural Senegal during the colonial period this practice largely ended when cash-cropping enabled younger men to acquire resources of their own and marry earlier than before (Buggenhagen 2012). But as these young men grew older they, too, reproduced the polygynous arrangements they had so resented in their youth.

Following the emergence of feminist scholarship in the 1960s and 1970s, it became obvious that perspectives on marriage were gendered, and anthropological approaches helped to understand polygyny by examining the notions of gender and personhood on which the practice was predicated. Fainzang and Journet $(1988,1991)$, for example, have shown how, among Pulaar- and Soninke-speakers, polygyny was predicated on gender relations in which men consciously maintained competition among their spouses and used secrecy and the threat of additional wives to assert their power. More recently, Antoine and Nanitelamio (1995) have pointed to the enduring regional preference for cousin marriage, particularly among Wolof- and Pulaarspeaking communities, in which men are likely to marry a cousin first so as to fulfill familial expectations and later to make a second marriage for love or prestige. This repertoire of options is not available to women, however, an asymmetry Dial (2008) analyzes as the main reason that Dakarois women use divorce strategically: whereas men accumulate wives, women tend to divorce and remarry quickly to avoid the stigma attached to single women. Indeed, marriage and procreation remain central in the construction of female status, an idea expressed by a married Senegalese woman in her mid-thirties at the time of interview: "If you're not married, nobody listens to you. My sister who is 40, who never married, doesn't get much respect. People just say she didn't even manage to find a husband." The centrality of marriage for women's status means that in Dakar, for example, most women divorcees remarry within four years of a divorce (Dial 2008). But remarriage usually means becoming a second or third wife, and women in their thirties or forties rarely become first wives. This pattern helps us understand why women who aspire to companionate marriage might find it preferable to marry a foreigner than remain unmarried or risk being locked into a cycle of marriage, polygyny, divorce, and remarriage into polygyny.

At the same time, marriage to Europeans is not a new phenomenon. This history goes back to the seventeenth century and the beginnings of French trade in Senegambia (White 1999; Jones 2013) when young French men sent to the Senegambian Coast to trade in slaves and other "commodities" developed relationships with local women. "Customary marriage," as the practice was called, fostered the growth of elite creole communities in coastal trading posts like SaintLouis at the mouth of the Senegal River and Gorée Island just off the Cape Verde Peninsula. During the colonial period, however, interracial marriages became frowned upon, even though many colonial officers continued to establish families with African women (Dilley 2014). When French-educated Senegalese literati, or évolués, started traveling to France in growing numbers in the first half of the twentieth century, 
marriage to European women became a mark of status for educated elite men. But the same was not true of Senegalese women marrying European men, and it was only with the wider access of women to schooling and travel abroad from the 1970s onward that Senegalese women began to marry European men more frequently. In short, the history of Senegalese-European marriage is at once gendered and inflected with class (Neveu Kringelbach 2015).

This colonial history goes some way toward explaining why marriage between Senegalese women and European men is often perceived as morally ambiguous in Senegal, and why most of the women concerned are faced with the disapproving gaze of family members and friends. In addition, while interethnic marriage is common in the region, endogamy has long been a valued ideal in several of the major linguistic groups, particularly among Pulaar speakers (Wane 1969). In Wolof, the danger of marrying across boundaries is captured by proverbs such as "Ku wacc sa andd, andd boo yeek mu todj" (Whoever leaves their incense pot [used by women to perfume their bodies] may end up sitting on a pot that will break). In practice the preference for endogamy remains gendered, however, and Senegalese men marrying European women generally face less opposition than Senegalese women marrying European men. It would be beyond the scope of this article to discuss all of reasons for this inequality, but these include the fear that the children born of a European father may not be raised as proper Muslims, and that they may be lost to the Senegalese family. This may be compounded by the enduring importance of bridewealth in the region (Diop 1985; Buggenhagen 2012): in some families, there is a fear that European grooms may refuse to become involved in a marriage process they regard as too inflected with material exchanges. As one Wolof-speaking Senegalese woman in her mid-forties at the time of interview, who lives in France and who had several European husbands put it, "My family never received bridewealth [dot in French, warugar in Wolof] from any of my husbands. I know that in this sense, they feel I have never honored them."

The desire for companionate marriage expressed by many of the women I interviewed also has historical antecedents, and it seems that by the 1960s many middle-class city-dwellers had such aspirations. In 1960, for example, the Francophone African magazine Bingo published a special issue on the aspirations of "the African youth." The series featured interviews with young West African men and women, mainly schoolteachers and civil servants. Although individual views on polygamy varied greatly, many testimonies were marked by contradiction. A number of men thus declared themselves opposed to polygamy while also pointing out its advantages "for women in the rural areas," as in this testimony by a thirty-two-yearold Senegalese schoolteacher:

We are in-between two generations and we feel torn between what we are allowed to do and what we would like to do. With its arsenal of old customs, African society forms a barrier that is often very difficult to cross. Among family especially, we cannot impose our modern vision of life without clashes and rustling. I am monogamous, even though I am a Muslim. It's my vocation. But for now this kind of vocation is not to everyone's taste. . . And I must admit that polygamy is necessary in the rural areas, so long as women depend on men materially and intellectually, so long as they are not conscious of being free individuals who belong only to themselves. ... Many young people of my age feel uncomfortable in this transitional state that is bound to last ten, twenty years and from which we will only escape through the 
education of women, and their access to professions that will enable them to be autonomous. (Bingo 1960:9, my own translation from French)

Predictably, most educated women saw polygamy as opposed to companionate marriage. One Muslim woman, a married schoolteacher in her twenties, thus stated that "love [was] the very basis of marriage, and love [could] only have one face" (Bingo 1960:11). Yet women's perspectives were infused with contradictions, too, as in the comments of a divorcee with three children who praised polygamy while also claiming that a man could not possibly "divide his heart" (Bingo 1960:13). The testimonies were undoubtedly edited to fit Bingo's modernizing perspective. Nevertheless, they likely reflect aspirations by the educated Senegalese youth of the late colonial period to transform marriage ideals.

Written later but with similar concerns, Mariama Bâ's (1979) novel Une Si Longue Lettre sketches the lives of two mature Senegalese women through the letters written by Ramatoulaye to her longtime friend Aïssatou. Both women belonged to a small elite of women educated in the late years of French colonialism. Before we meet them in the novel they had both married educated Senegalese men with whom they shared ideas about romantic love and monogamous marriage. By the time their husbands had become mature men, however, their perspective had changed and they had each married a much younger, second wife (ñarel). Whereas Aïssatou chose divorce, resumed her education, and moved abroad with her children, Ramatoulaye stood by her husband. In the letters she writes to her friend after his death, she narrates the years she has endured as an ageing, abandoned, and betrayed first wife (aawo). Like some of the young adults featured in the Bingo issue, the two women feel cheated of the "modern" marriages they had aspired to.

Before scholarly accounts caught up to the fact that the practice of polygyny was not about to disappear, Bâ's novel vividly illustrated that earlier predictions about the decline of polygyny had been misguided. Some of the young women aspiring to companionate marriage have therefore chosen to marry Europeans. I now turn to the narratives of women who have remained in Senegal with their husbands.

\section{The View from Senegal: Tales of Misfortune and the Morality of Marriage}

On a hot afternoon in Dakar, I arrived at Rokhaya's house for a chat. Rokhaya was a cheerful, successful Wolof woman in her mid-thirties who lived in a tastefully decorated house with her French husband and their young children. That afternoon, she introduced me to her sister, Rama, whom I had not met before. There was a physical resemblance between them, but in other ways they seemed very different: whereas Rokhaya was articulate, outspoken, and spoke fluent French, Rama seemed quiet. Before long, I realized that she hardly spoke French, and that I would have to use my mediocre Wolof to communicate with her. This was not unusual in Dakar, but what was striking was the contrast between the two sisters. Rokhaya later explained that unlike herself, her sister had attended school for only a brief period of time before being confined to domestic work. Shortly before Rokhaya was born her father had married a third wife. As the second wife, Rokhaya's mother was exhausted with the constant domestic conflicts, and she had decided to return to her parents' hometown with the baby. She had stayed there for a couple of years, during which time her husband visited on several occasions to claim her back. The separation from her other children caused Rokhaya's mother a great deal of suffering, however, and she eventually agreed to return to her husband's home in Dakar. 
Upon return, Rokhaya's mother was dismayed to find that her older daughters, including Rama, had been taken out of school, much against her wishes. Since she had been away for so long, Rokhaya explained, her co-wives had taken the opportunity to compromise the education of her children, likely with a view to weakening her future status. It was unclear from the story why the children's father had agreed to this. Thanks to her mother's determination, Rokhaya herself was sent to school, and eventually was sent away to a small town to live with some of her maternal relatives, apparently because her mother feared that she would be harmed by the co-wives. Even as an adult Rokhaya resented the separation and felt that the relatives exploited her for domestic work more than they had supported her education.

Rokhaya eventually returned to Dakar as a young adult. Soon after her foster parents traveled to Dakar to ask Rokhaya's father for her hand in marriage for their adult son. As a cousin, he belonged to the category of preferred spouses in Wolof kinship, and the relatives also believed that Rokhaya's parents were morally indebted to them for caring for her. But Rokhaya had no desire to become their daughter-inlaw, especially since her foster father had taken a second wife in the meantime. She had no doubt that the son would eventually follow in his father's steps and take a second wife. Rokhaya explained that she did not want to suffer in a polygamous marriage the way her mother did. She eventually decided to marry a young French man she had met in Dakar. Her parents' initial opposition floundered when they realized that she would never agree to marry a cousin, and when the young man converted to Islam. For her parents, this was still a better option than seeing her remain unmarried. When Rokhaya and her husband had children, they made a point of giving them Muslim names and raising them as Muslims. This likely went a long way toward winning the approval of her parents, who also came to like her husband as a person.

Given the pressure Rokhaya had faced to marry a cousin, her choice to marry out of romantic love was a strong statement of autonomy. But it was important to her that she did not alienate her family in the process. Her perspective on marriage had clearly been shaped by her disillusion with polygyny. But a moralizing thread also ran through her narrative, which implied that she had been forced to break with her family's expectations in order to protect herself from what she saw as the corrupting influence of modern Wolof kinship, in which relations of exchange (such as raising the children of relatives or dependents in return for domestic help) quickly turn into exploitative practices. She often emphasized how emotional attachment should be dissociated from material exchange, and how she thought Islam was often invoked wrongly to justify practices such as neglecting the education of girls.

Rokhaya's trajectory exemplifies the experience of many West African individuals who grew up in contexts of "distributed parenthood" (Coe 2014:62). But polygyny in particular complicates childhood experiences and often generates differentiated access to education among children by different mothers. This may be due to family conflicts, as in Rokhaya's case, or simply because there is an average of fifteen years between a man's first marriage and his second (Antoine \& Nanitelamio 1995), and during this time his financial situation may have worsened. Such differentiation is captured by the Wolof term doomu baay (literally "father's children") to designate half-siblings by the same father but different mothers: the bond between them is believed to be ambiguous, simultaneously close and competitive, supportive and dangerous.

Rokhaya's story also expresses the disillusion with polygyny, and more generally with gender relations in marriage, that was a running thread in all of the testimonies I 
collected in Senegal, not only among Wolof women but also among Sereer- and Pulaar-speakers. Compromised education and long periods of separation from parents, as well as illness and death, were often interpreted as consequences of polygyny, through the strategies deployed by co-wives to maintain the affection of their husband and secure the future of their own children.

For Saly, a Sereer woman in her mid-thirties who owned a small business and who had also married a French man, there was no doubt that her mother's illness and subsequent death were ultimately caused by polygyny. Her mother had been a first wife, and initially at least, the couple had enjoyed a simple but comfortable life in a home they had bought through a government-sponsored housing scheme. Several years into the marriage, Saly's father had married a second, younger wife. Saly said her strongest childhood memories were of returning home from school every day to witness yet another dispute between her mother and the second wife. She often found refuge at the local cinema, where the love stories and the visual flamboyance of Hindi films provided a soothing counterpoint to the troubled home. Some years into the second marriage the younger wife became ill and died, and the woman's family members accused Saly's mother of engineering her death through occult means. From then on, Saly explained, these accusations poisoned her mother's life and ultimately made her ill.

Unlike some of the women I interviewed, Saly did not make an explicit connection between her mother's experience and her own marriage choice, yet she often claimed that she had known early on that she would not marry a Senegalese man. "People saw it in me," she said; "everybody in the neighborhood said I would marry a white man." Some of her parents' siblings had initially resisted her marriage to a French man, but they had been won over by the fact that he had converted to Islam long before proposing. Saly made a point of visiting her mother often when she was still alive, and of showing generosity toward her extended family.

Through their family narratives, then, the women I encountered in Dakar often moralized their alternative marriage choices by emphasizing the contrast between their own moral standards and what they saw as the morally compromised, at times un-Islamic, character of modern Senegalese marriage. These elements also figured prominently in the narratives I collected in France, although these emphasized the ideal of companionate marriage to an even higher degree, most likely because the women in France now lived in a context in which this was the only aspiration deemed acceptable.

\section{The View from France: Tales of Loss and Dreams of Romantic Love}

When I met Mariam in France, she had been living there for several years with her French husband. Like Rokhaya, she was very articulate about the cost of marrying against her family's wishes.

Mariam, a Halpulaar woman in her late thirties with a university degree and a stable office job, had grown up in Dakar with her parents. Her mother was her father's first wife. She had died of illness fairly young, when Mariam was still a child, and Mariam was convinced that her death had been brought about by the arrival of a second wife in the household. She referred to the sense of betrayal her mother had felt, and also to the occult practices many Senegalese believe co-wives engage in to harm their rivals or their children.

Much later more misfortune struck the family: one of Mariam's older sisters developed an illness and died a couple of years after giving birth to a boy. The first 
stages of her illness had been detected soon after the birth, but her husband had refused to have her treated because he thought it more important that she nurse the child until the age of two, and the treatment posed a threat to the baby. By the time she stopped nursing, it was too late. In the meantime, her husband had met another woman, who became his second wife while the sister was in the hospital, dying. Mariam's grief and anger were palpable as she remembered the events: "He abandoned her when she was ill. It suited him that she died. . . He could do whatever he wanted with his new wife!" Whether or not Mariam's cruel assessment was accurate, it revealed her poor opinion of Senegalese marriages, which she explicitly linked to her own aspirations: "I told myself I would do everything not to end up with this kind of life, not to wear myself out for someone who'd just abandon me for a second wife."

On one occasion when I visited Mariam I met her friend Dieynaba, another Senegalese woman in her late thirties, also married to a French man. Back in Senegal, Dieynaba's sister had married her longtime Senegalese boyfriend and had several children. Several years into the marriage the sister was struck by a life-threatening illness that required expensive treatment, and Dieynaba had funded her treatment at a private hospital in Dakar. She recovered, but Dieynaba soon discovered that some of the money she had sent to cover the medical expenses had enabled the husband to save enough to marry a second wife. Dieynaba's sister felt betrayed, and the relationship never quite recovered. Although Dieynaba did not explicitly link her own choice of a French husband to her sister's predicament, it was clear that she shared Mariam's disillusion with Senegalese marriage.

Both Mariam and Dieynaba had married French men against the wishes of senior men in their respective families: in Mariam's case the opposition had come from her eldest brother, and in Dieynaba's case from her father. Yet it had mattered greatly to both women that their families eventually came to accept their choices. Having turned their back on the Senegalese marriages they had been encouraged to look for, they both claimed the moral high ground as dutiful daughters, despite the fact that they lived far from home. Also, both had convinced their secular husbands to convert to Islam so that a proper Mosque wedding (takk) could be performed and their children could be raised as Muslims.

Mariam, in particular, showered her family with money and gifts whenever she could afford to. She was terribly hurt, therefore, when she brought a substantial gift to her elder brother during a trip to Senegal and he had barely looked at it. The main opposition to her marriage had come from him, and since her father's belated acceptance had won out in the end, Mariam interpreted his disdain as a sign that their sibling relationship was profoundly damaged. Yet she had not given up on working to maintain her position and image of moral rectitude.

Her point of view contrasted strongly with that of Yacine, a Wolof woman who, after several marriages to European men, seemed to have resigned herself to the moral ambiguity of her position. By the time I met Yacine, she was living with her third European husband. She was a fiercely independent woman in her forties, with a stable job and a degree from a French university. Yacine told me that she had always known that she would leave Senegal and would "not marry an African man." This rejection was grounded largely in childhood memories of women in her family and her neighborhood whom she often saw seeking refuge from abusive husbands. She spoke of "broken arms and blood-covered faces." But Yacine had also decided early on that polygyny had devastating effects on women's physical and mental health. She experienced this in a very intimate way when her older sister's husband decided to 
take a second wife. The couple had been married for many years and had several children. Yacine described her sister's feelings: "She was shocked! She really loved him. He was 'her' man, she always cared for him ... She even bought his underwear whenever she traveled. She felt completely betrayed."

As is often the case with the impending arrival of a new wife, it was not the husband who broke the news to his first wife. A relative of his came to see her on the wedding day and apologetically told her that she was about to have a co-wife. Once the wedding was over, her own family requested that she visit her new co-wife and bring her a gift of welcome. In Yacine's view this lack of consent was against the Islamic prescription that consent must be sought from the first wife before a second wife can be wed. She also believed that few men were capable of following the Islamic duty of treating their wives equally. Like many Dakarois women, then, Yacine both repudiated the religious legitimization of polygyny that is commonly invoked by Senegalese men and also professed her own adherence to Islamic values, thus claiming the moral and religious righteousness of her own actions.

According to Yacine, the humiliating arrival of a co-wife transformed her sister's behavior. Whereas she had previously dressed simply, she began to use makeup and wear extravagant outfits, and to bestow expensive gifts on family members. As Buggenhagen (2012) has shown, Muslim women in Dakar assert their value partly through gift-giving, particularly during naming ceremonies and weddings. Gift-giving during family ceremonies is thus a highly significant gesture through which women insert themselves into circuits of exchange. According to Yacine, her sister went from occasional, modest participation to blatantly attempting to outperform her co-wife in this regard. In describing the competition her sister was drawn into, Yacine spontaneously mentioned Mariama Bâ's novel: "Have you read Une Si Longue Lettre?" she asked; "It was exactly like that!" Sadly, the family did not realize that Yacine's sister's conspicuous generosity covered a profound despair: "She sank into depression, but we didn't see it at first. You know how it is back home, we don't talk about these things. No one says anything. ..."

By the time they noticed, it was too late, and the sister took her own life. For Yacine, there was no doubt that this was a direct consequence of the deep sense of humiliation and betrayal her sister had felt. More than a decade later, Yacine found the grieving process all the more difficult as the suicide was silenced in the family; the death, according to custom, was commemorated every year, but the family said that the sister had died of illness. The tragic loss of her sister made Yacine more determined than ever not to marry a Senegalese man, even after her first two marriages had failed.

Yacine's marriage aspirations, however, were not exclusively determined by a rejection of polygyny. She also longed for romantic love and genuine companionship in marriage, and doubted that she would find this in a conventional Wolof marriage. For some of her sisters and cousins, marrying well meant marrying someone with money and respectability. Yacine, by contrast, emphasized the moral value of her own marriage aspirations, which she saw as untainted by material considerations. As a child, she said, she used to watch American television series like Dallas and Dynasty: "I saw couples who loved each other, who held hands and showed their affection. ... It was very different from what I saw around me, but I always dreamt of that." She felt a special connection to her mother, which was grounded in a shared longing for romantic love: "People criticized my mother for being too protective of me when I got married. But I think that if she had been my age, she would have done the same. She always looked for love, but didn't find it in her marriage." 
There was strong opposition to Yacine's marriage to her first French husband, and her father only gave in after her then fiancé threatened to commit suicide if they kept rejecting him. But whenever they visited Senegal she suffered from the condescending gazes that she was subjected to in public: "People at the market called me a prostitute sometimes," she recalled with sadness. Like other women in mixed marriages, Yacine suffered from being considered a "free" woman, a term carrying a negative connotation in a Senegalese context. But her desire for companionate marriage has been stronger than her desire to conform to social expectations, and over the years she has even come to relish the freedom that comes with being considered a lost cause. Still, Yacine still goes to great lengths to show that she has remained a dutiful daughter and sister, and she has supported the emigration of several of her nieces and nephews.

\section{Conclusion}

In this article I have examined the question of why, in a Senegalese context in which marriage ideals continue to emphasize familial alliances, reproduction, material security, and religious obligations, some women marry European men, often at great cost to their social relations. To address this question, I have drawn on the autobiographical narratives of several women, some of whom live in Senegal and others who live in France. The narratives emphasize three interrelated aspects of the women's experience. First, they show that for them, polygyny is too often invoked as a cultural practice to conceal exploitation and competition within families. Second, the narratives point to the role of childhood and youth experiences in shaping ideals of love and marriage, and life aspirations more generally. Third, they emphasize the moral fragility of female agency in contemporary Senegal.

Indeed, the women I have encountered had all made the choice of fulfilling their own aspirations in the face of strong familial opposition, although their assertions of independence did not leave them free to live their lives as they pleased. On the contrary, most of them felt compelled to demonstrate that they lived up to social expectations in all other ways: they showed generosity to siblings and ageing parents, whom they cared for regardless of where they lived, and in some cases regardless of the inconvenience or what they could easily afford financially. Those who lived in Senegal often housed relatives for long periods of time, despite the tensions this might generate with their spouses. They also convinced their European spouses to convert to Islam, at least nominally if not through a full conversion process. These details resonate with studies of love and marriage in other parts of Africa, in which scholars have shown that the increasing salience of romantic love in modern marriages does not diminish social expectations. The women, therefore, often go to great lengths to emphasize the moral righteousness of their choices by zealously fulfilling familial and religious duties.

The narratives themselves also play an important role in upholding the moral basis of the women's acts of individual agency. Most of them framed family relationships in contemporary Senegal as morally compromised by the relentless search for monetary gain. Rokhaya, for example, attributed her difficult years as a foster child to the desire of her relatives to exploit her for domestic labor rather than care for her education. In turning their back on some of the exploitative practices they suffered as children, these women establish a moral connection to an imaginary time when Wolof kinship was about solidarity rather than accumulation. 
Here I return to one of the broader questions raised in the introduction, which is the role of autobiographical narrative in linking past experiences to aspirations for the future. The narratives were told to me as a researcher, as the child of a French-Senegalese relationship, and sometimes as a friend, but these were also stories the women told themselves. Although I knew enough about the women's lives and the context in which they grew up to verify that the narratives were grounded in actual experience, the crafting of the stories was significant. The recurring theme of misfortune as a consequence of polygyny, for example, was at once grounded in genuinely felt grief, and shaped by a strong global discourse on gender-based violence. Global discourses circulate in multiple ways, not least through the mediawhich many of the women I interviewed mentioned in relation to their aspirations to romantic love in marriage - and in everyday conversations among peers. Undoubtedly, the rising global focus on gender-based violence helped these middleclass and often well-traveled women to make sense of the link between personal experiences and life aspirations. There is a class dimension to this, but it is significant that there was no major difference between those women who lived in Senegal and those who lived in France when it came to associating female misfortune with polygyny and violence in marital relations.

The second broader question concerns the extent to which rising aspirations to transnational lives among African women transform ideas about marriage, love, and gender. As we have seen, the ideal of companionate marriage is not an entirely new phenomenon in Wolof society, but rather has coexisted with a preference for cousin marriage and polygyny for at least several generations. In the household that I visited as a child, for example, several practices coexisted. The first marriage had been a love marriage but it had remained childless, and the value placed on reproduction in Wolof society had thus pushed the husband into a second marriage. Polygyny enabled him to enter into two marriages for different reasons, thus showing how different ideals may be mobilized at different times in an individual's life. Eventually, however, polygyny caused the first marriage to break down, and the husband ended his life in monogamy. His daughter, having experienced polygyny as a child, chose companionate marriage with a European man.

Of course, even the choices of this daughter and of the women in my study in some ways express the limits of individual agency in transforming notions of marriage in contemporary Senegal. In the end, that is, even women who question the moral and religious validity of polygyny must still marry to achieve social adulthood; remaining single is just not an option. In addition, the choices they made seem to be available largely to middle-class women as opposed to women from poorer families. In this sense, it may well be that in contemporary Senegal companionate marriage itself is predominantly a middle-class aspiration. It may also be a development that is leaving many Senegalese men in the unenviable position of being regarded by many women as inadequate potential husbands. However, it is undeniable that change is noticeable, and that opportunities for Senegalese women to marry spouses from other parts of the world have increased their options. At least for middle-class women, such marriages take place on fairly egalitarian terms, and represent a significant change from the colonial and precolonial periods.

\section{References}

Ames, David W. 1955. "The Economic Base of Wolof Polygyny." Southwestern Journal of Anthropology 11 (4): 391-403. 
ANSD. 2012. "Enquête Démographique et de Santé à Indicateurs Multiples Sénégal (EDS-MICS) 2010-11.” Dakar: Agence Nationale de la Statistique et de la Démographie (ANSD).

Antoine, Philippe, and Jeanne Nanitelamio. 1995. "Peut-on échapper à la polygamie à Dakar?" Chronique du CEPED 32.

Bâ, Mariama. 1979. Une Si Longue Lettre. Dakar: Nouvelles Editions Africaines

Bingo. 1960. "Une enquête de Bingo: La jeunesse d'Afrique vous parle. . . .." January.

Bloch, Alexia 2011. "Intimate Circuits: Modernity, Migration and Marriage among Post-Soviet Women in Turkey." Global Networks 11 (4): 502-21.

Bop, Codou. 1996. "Les femmes chefs de famille à Dakar." In Femmes du Sud, Chefs de Famille, edited by Jeanne Bisilliat, 129-50. Paris: Karthala.

Buggenhagen, Beth A. 2012. Muslim Families in Global Senegal: Money Takes Care of Shame. Bloomington: Indiana University Press.

Burnham, Philip. 1987. "Changing Themes in the Analysis of African Marriage." In Tranformations of African Marriage, edited by David Parkin and David Nyamwaya, 37-54. Manchester: Manchester University Press.

Charsley, Katharine. 2012. "Transnational Marriage." In Transnational Marriage: New Perspectives from Europe and Beyond, edited by Katharine Charsley, 3-22. London: Routledge. . 2013. Transnational Pakistani Connections: Marrying 'Back Home.' London: Routledge.

Coe, Cati. 2014. The Scattered Family: Parenting, African Migrants, and Global Inequality. Chicago: University of Chicago Press.

Cole, Jennifer. 2014. "Working Mis/understandings: The Tangled Relationship between Kinship, Franco-Malagasy Binational Marriages, and the French State." Cultural Anthropology 29 (3): 527-51.

Constable, Nicole. 2005. Cross-Border Marriages: Gender and Mobility in Transnational Asia. Philadelphia: University of Pennsylvania Press.

Creevey, Lucy. 1996. "Islam, Women, and the Role of the State in Senegal." Journal of Religion in Africa 26 (3): 268-307.

Dial, Fatou B. 2008. Mariage et Divorce à Dakar. Paris: Karthala.

Dilley, Roy M. 2014. Nearly Native, Barely Civilized: Henri Gaden's Journey through Colonial French West Africa (1894-1939). Leiden: Brill.

Diop, Abdoulaye-Bara. 1985. La Famille Wolof. Paris: Karthala.

Fainzang, Sylvie, and Odile Journet. 1988. La Femme de Mon Mari. Paris:

L'Harmattan.

1991. "L'Institution polygamique comme lieu de construction sociale de la féminité." In Sexe et Genre: De la Hiérarchie entre les Sexes, 217-25. Paris: Centre National de la Recherche Scientifique.

Fair, Laura. 2009. "Making Love in the Indian Ocean: Hindi Films, Zanzibari Audiences, and the Construction of Romance in the 1950s and 1960s." In Love in Africa, edited by Lynn M. Thomas and Jennifer Cole, 58-82. Chicago: University of Chicago Press.

Fernandez, Nadine T. 2013. "Moral Boundaries and National Borders: Cuban Marriage Migration to Denmark." Identities: Global Studies in Culture and Power 20 (3): 270-87.

Goode, William. 1964. The Family. Englewood Cliffs, N.J.: Prentice Hall 
Goody, Jack. 1973. "Polygyny, Economy and the Role of Women." In The Character of Kinship, edited by Jack Goody, 175-90. Cambridge, U.K.: Cambridge University Press.

Groes-Green, Christian. 2014. "Journeys of Patronage: Moral Economies of Transactional Sex, Kinship, and Female Migration from Mozambique to Europe." Journal of the Royal Anthropological Institute 20: 237-55.

Hannaford, Dinah. 2015. "Technologies of the Spouse: Intimate Surveillance in Senegalese Transnational Marriages." Global Networks 15 (1): 43-59.

Hannaford, Dinah, and Ellen E. Foley. 2015. "Negotiating Love and Marriage in Contemporary Senegal: A Good Man Is Hard to Find.” African Studies Review 58: 205-25.

Hirsch, Jennifer S., and Holly Wardlow. 2006. Modern Loves: The Anthropology of Romantic Courtship and Companionate Marriage. Ann Arbor: University of Michigan Press.

Jones, Hilary. 2013. The Metis of Senegal: Urban Life and Politics in French West Africa. Bloomington: Indiana University Press.

Meillassoux, Claude. 1960. "Essai d'interprétation du phénomène économique dans les socitétés traditionelles d'autosubsistance." Cahiers d'Etudes Africaines 4: $38-67$. 1975. Femmes, Greniers et Capitaux. Paris: Maspero.

Mutongi, Kenda. 2009. “'Dear Dolly's' Advice: Representations of Youth, Courtship, and Sexualities in Africa, 1960-1980." In Love in Africa, edited by Lynn M. Thomas and Jennifer Cole, 83-108. Chicago: University of Chicago Press.

Ndiaye, Salif, Papa Demba Diouf, and Mohamed Ayad. 1994. "Enquête Démographique et de Santé au Sénégal (EDS-II) 1992/93.” Dakar: Direction de la Prévision et de la Statistique.

Neveu Kringelbach, Hélène. 2013. Dance Circles: Movement, Morality and SelfFashioning in Urban Senegal. Oxford: Berghahn Books. . 2015. "Gendered Educational Trajectories and Transnational Marriage among West African Students in France." Identities: Global Studies in Culture and Power 22 (3): 288-302.

Rytter, Mikkel. 2013. Family Upheaval: Generation, Mobility and Relatedness among Pakistani Migrants in Denmark. Oxford: Berghahn Books

Salomon, Christine. 2009. "Vers le nord." Autrepart 49: 223-40.

Sow, Fatou, Anne C. Rennick, and Catherine Boone. 1989. "Senegal: The Decade and Its Consequences." Issue: A Journal of Opinion 17 (2): 32-36.

Thomas, Lynn M. 2009. "Love, Sex, and the Modern Girl in 1930s Southern Africa." In Love in Africa, edited by Lynn M. Thomas and Jennifer Cole, 31-57. Chicago: University of Chicago Press.

Thomas, Lynn M., and Jennifer Cole. 2009. "Thinking through Love in Africa." In Love in Africa, edited by Jennifer Cole and Lynn M. Thomas, 1-30. Chicago: University of Chicago Press.

Wane, Yaya. 1969. "Les Toucouleur du Fouta Tooro, stratification sociale et structure familiale." Initiations et études africaines (IFAN) 25.

Wardlow, Holly, and Jennifer S. Hirsch. 2006. "Introduction." In Modern Loves: The Anthropology of Romantic Courtship and Companionate Marriage, edited by Jennifer S. Hirsch and Holly Wardlow, 1-31. Ann Arbor: University of Michigan Press.

White, Owen. 1999. Children of the French Empire: Miscegenation and Colonial Society in French West Africa, 1895-1960. Oxford: Oxford University Press. 


\section{Notes}

1. I use the term polygyny rather than polygamy since there are no known cases of polyandry in Africa. In Francophone countries, however, the term polygamy is preferred, both in scholarly texts and in everyday speech.

2. See www.migration.ox.ac.uk/odp/multinational-families.shtml.

3. Genn xeet can be translated roughly as "to leave the group" or "the person who is outside the group," with the group referring to race, ethnicity, or caste.

4. According to the most recent Demographic and Health Survey, 35\% of married women in Senegal lived in polygynous unions (ANSD 2012). The surveys carried out in the 1970s and 1990s were less detailed and the comparison is therefore unreliable, but they point to a gradual decrease: according to a 1993 population survey, $60 \%$ of Senegalese women over thirty-five were in a polygynous marriage, with little change from 1978 (Ndiaye, Diouf, \& Ayad 1994).

5. Comments from participants have been translated from French. 